\title{
Yield and Seed Quality of Summer Green Gram as Influenced by Weed Management under Zero Tillage
}

\author{
Kuldeep Singh ${ }^{1}$, Hardev Ram, Rakesh Kumar, R.K. Meena, A. Saxena,
} Rakesh Kumar, Ankit Kumar, B.R. Praveen, Pawan Kumar

$10.18805 / L R-4752$

\begin{abstract}
Background: Weeds are primary factors that adversely affect growth, yield and seed quality of summer green gram, which can be minimized with adoption of proper weed management practices. This field experiment was conducted to find out the effective weed management practice in summer green gram (Vigna radiata) under zero tillage condition.

Methods: In this field-laboratory investigation conducted during summer season 2019 on different herbicides were applied to manage weeds in summer green gram. Eight treatments were applied based on various application windows. In the field and laboratory, the collected samples were determined for growth parameters, nutrient uptakes, seed yield and seed quality of summer green gram. Result: The result revealed that weed free treatment recorded higher growth parameters like, plant height, number of branch/plant, number of leaves/plant and root biomass which was statically at par with Shaked (Propaquizafop + Imezathyper) as post-emergence (POE) at 20 DAS and Pendimethalin as pre-emergence (PE) followed by one hand weeding 20 DAS. Same trends were also observed in seed yield, nutrient content and uptake by seeds. Seed quality parameters like germination per cent (98.00), shoot $(25.63 \mathrm{~cm})$ root $(14.20 \mathrm{~cm})$ and seedling length $(39.83 \mathrm{~cm})$, seedling dry weight $(0.16 \mathrm{~g})$, vigour index I (3903.33) and vigour index II (14.96) was higher under weed free followed by Shaked (Propaquizafop + Imezathyper) and Pendimethalin as (PE followed by one hand weeding 20 DAS over weed check.
\end{abstract}

Key words: Seed quality, Summer green gram, Vigour index, Weed management.

\section{INTRODUCTION}

Pulses are playing an important role in Indian economy as well as socio-economic condition. Pulses are rich source of protein, vitamins, fibers and minerals (iron, zinc and magnesium) and some essential amino acids which are plays a vital role in human health (Yadav et al., 2017). Most of Indian populations are vegetarian and pulses also contribute to about $14 \%$ of total protein supplementation of a usual diet of India. Pulses occupy a leading place in various cropping system and grow as main crop, cover crop, catch crop, inter crop and green manure crop (Mallikarjun et al., 2021). Pulses improve soil health by enhanced soil physical, biological and chemical properties as well as soil fertility status through biological nitrogen fixation with symbiotic association with rhizobium from the atmosphere and mushrooming the soil microorganism population in soil. (Peoples et al., 2018).

Green gram (Vigna radiata) is an important short duration legume crop in India. It is quite versatile crop can be grown for seeds, green manure and forage as mixed or sole crop. Mungbean contains about $51.6 \%$ carbohydrate, 26 to $27 \%$ protein, 4 to $5 \%$ minerals and 3 to $4 \%$ vitamins (Dhakal et al., 2015). Green gram can be grown in summer season where sufficient irrigation dexterity is feasible. In summer season less extra rainfall, less cloudy condition, higher temperature and less humidity provide less infestation of pest and disease. Growth and productivity of mungbean affected by many biotic and abiotic factors like nutritional deficiency, water scarcity, pest and disease etc. Weeds are
ICAR- National Dairy Research Institute, Karnal-132 001, Haryana, India.

${ }^{1}$ Soil Science and Agricultural Chemistry, SKN Agriculture University, Jobner-303 328, Rajasthan, India.

Corresponding Author: Hardev Ram, Department of Agronomy, ICAR-National Dairy Research Institute, Karnal-132 001, Haryana, India. Email: devagron@gmail.com

How to cite this article: Singh, K., Ram, H., Kumar, R., Meena, R.K., Saxena, A. and Kumar, R. (2022). Yield and Seed Quality of Summer Green Gram as Influenced by Weed Management under Zero Tillage. Legume Research. DOI: 10.18805/LR-4752.

Submitted: 28-07-2021 Accepted: 09-11-2021 Online: 10-01-2022

one of the most important factors to reduce yield of mungbean during summer and rainy season (Singh et al., 2021). Being a short duration crop, it faces heavy weed competition right from the early growth stages (Pandey et al., 1999). Weed competition is very high during initial 25-30 days of mungbean (Raghvani et al., 1985). Weeds alone reduce mungbean yield up to $90 \%$ depending upon cultivars, soil moisture level, soil types, field condition and other environmental constraints (Kumar et al., 2006 and Ali et al., 2011). The yield loss of mungbean mainly depends upon types of weed flora, its intensity and period of crop-weed competition (Choudhary et al., 2016).

The progressive conversion of agriculture concerning intensive use of herbicides is gaining status in recent years 
Yield and Seed Quality of Summer Green Gram as Influenced by Weed Management under Zero Tillage

due to easy, lower cost and timeliness and success in controlling weeds (Butter et al., 2008). Chemical weed controls an excellent alternative to manual as well as mechanical weeding and supply weed-free environment during early growing stage up to 30-35 days (Dungarwal et al., 2003, Das and Yaduraju, 2011, 2012). Therefore, keeping above information in view, the present study was conducted to assess the effect of different weed management practices in summer green gram under zero tillage condition to find out the better combination of weed control means to get higher growth and quality of seed.

\section{MATERIALS AND METHODS}

The experiment was conducted at Agronomy Research Farm, ICAR-National Dairy Research Institute, Karnal and Haryana, located at $29^{\circ} 41^{\prime} \mathrm{N}$ latitude and $76^{\circ} 58^{\prime} \mathrm{E}$ longitude with an altitude of $245 \mathrm{~m}$ above mean sea level in Trans Indo-Gangetic Plain of India during summer season of 201920. The soil of experiment field was clay loam in texture having neutral $\mathrm{pH}$ (7.32), medium in Walkley-Black organic carbon $(0.53 \%)$ and low in $\mathrm{KMnO}_{4}$ Oxidizable nitrogen (164 $\mathrm{kg} / \mathrm{ha}$ ), medium in $0.5 \mathrm{M} \mathrm{NaHCO}_{3}$-extractable phosphorus $(19.5 \mathrm{~kg} / \mathrm{ha})$ and $1 \mathrm{~N} \mathrm{NH}_{4} \mathrm{OAC}$ extractable potassium (227.7 $\mathrm{kg} / \mathrm{ha}$ ). The experiment was conducted in randomized block design consisting of eight treatments viz., $\mathrm{T}_{1}$-Weedy check, $\mathrm{T}_{2}$-Weed free, $\mathrm{T}_{3}$-Pendimethalin (pre-emergence) @ 0.75 $\mathrm{kg} / \mathrm{ha}, \mathrm{T}_{4}$-Pendimethalin followed by hand weeding at 20 DAS, $T_{5}$-Imezathyper (Post emergence) @ $75 \mathrm{~g} / \mathrm{ha}$ at 20 DAS, $\mathrm{T}_{6}$-Shaked (Propaquizafop + Imezathyper) (2 l/ha) as post emergence, $T_{7}$-Pendimethalin @ $0.75 \mathrm{~kg} / \mathrm{ha}$ followed by Imezathyper @ $75 \mathrm{~g} / \mathrm{ha}$ at 20 DAS and $\mathrm{T}_{8}$-Pendimethalin @ $0.75 \mathrm{~kg} / \mathrm{ha}$ followed by Quizolofop ethyl @ $50 \mathrm{~g} / \mathrm{ha}$ at 20 DAS replicated thrice.

The recommended dose of fertilizer (20:30:40 kg NPK/ ha) was applied as basal in the form of Urea, DAP and MOP, respectively. The required quantity of seeds $(20 \mathrm{~kg} / \mathrm{ha})$ was treated with rhizobium culture and phosphorus solubilising bacterial (PSB) before sowing @ $20 \mathrm{~g} / \mathrm{kg}$ of seed. The seeds were sown in row drawn $30 \times 10 \mathrm{~cm}$ apart with $5 \mathrm{~cm}$ deep of variety $\mathrm{MH}-421$ The herbicides were applied as per treatments using knapsack sprayer fitted with a flat-fan nozzle. One hand weeding was done at 20 days after sowing as per treatment. A total six irrigations were given to the crop at 4, 17, 24, 38, 50 and 62 days after sowing. To eliminate border effect; two rows on both sides and $0.5 \mathrm{~m}$ length at each end of the plot was not included in the experiment and net plot area gross plot $\left(5 \times 4 \mathrm{~m}^{2}\right)$ and net plot area $\left(4.3 \times 3 \mathrm{~m}^{2}\right)$ was harvested separately from each plot.

Seed samples were collected from seed lot of each treatment and stored in cloth bags. Hundred seeds were taken for seed quality parameters viz: germination (\%), Seedling length $(\mathrm{cm})$ and seedling dry weight $(\mathrm{g})$. Test weight from seed sample of seed of seed lot of each plot were taken randomly and weighed separately. The seeds were placed for standard germination at $25^{\circ} \mathrm{C}$ for 8 days in rolled towel paper (B.P. Method) (ISTA Method, 2019).
Germination percentage $=$

$$
\frac{\text { No. of seeds germinationed }}{\text { Total no. of seeds }} \times 100
$$

Five seedlings were taken randomly from germinated seedlings of each plot and their length was measured with the help of centimetre scale and average was expressed as seedling length in centimetre $(\mathrm{cm})$ after that same five seedlings are dried in a hot air oven at $70^{\circ} \mathrm{C}$ till constant weight was obtained and average was expressed as dry weight $\mathrm{g} / \mathrm{seedling}$. The seedling vigour expressed after 8 days setting the experiment. Seedling Vigour Index was determined by the formula given by Abdulbaki and Anderson (1973).

Seedling vigour index I = Germination $\% \times$ Seedling length $(\mathrm{cm})$ Seedling vigour index $\mathrm{II}=$

Germination $\% \times$ Seedling dry weight $(g)$

Five plants were selected and recorded various growth data. The seed samples were collected at harvesting and oven dried $\left(70^{\circ} \mathrm{C}\right)$ then grinded in a wiley mill to pass through $2 \mathrm{~mm}$ sieve. The sieved samples were used for the estimation of nutrients contents in seed. Nutrient uptake by crop (seeds) are obtained by multiplying dry matter yield $\mathrm{kg} / \mathrm{ha}$ and nutrient content (\%).

Nutrien uptake $(\mathrm{kg} / \mathrm{ha})=$

Nutrient concentration in seeds $(\%) \times$ Dry matter $(\mathrm{kg} / \mathrm{ha})$ 100

Data on growth, seed quality parameters, nutrient contents and uptake were subjected to analysis of variance given by Gomez and Gomez (1984).

\section{RESULTS AND DISCUSSION}

\section{Effects on growth parameters}

Plant height, number of leaves/plant, number of branches/ plant and LAI was significantly affected by various weed control practices at 30 DAS and harvest (Table 1). It was noticed that above mentioned parameters were increasing trend with ageing of the crop. Weed free recorded highest plant height $(32.70$ and $57.00 \mathrm{~cm})$, number of leaves/plant (25.10 and 48.03) and number of branches/plant (4.30 and $5.87)$ at 30 DAS and harvest and LAI (4.11) at harvest followed by Pendimethalin as PE followed by one hand weeding at 20 DAS and Shaked (Propaquizafop + Imezathyper) as POE. In weedy check, it was recorded minimum growth parameters might be because of overcrowding of weeds during entire crop growth period. All other weed management treatments were recorded significantly higher growth parameters over weedy check. This might be due to efficient weed control and reduce the crop weed competition for available resources. Similar results were recorded by Komal et al. (2015).

The weed control practices were significantly affected the number and dry weight of nodules/plant and root biomass at 40 DAS (Table 2). The highest nodules number/ 
plant (27.03), nodule dry weight $(0.29 \mathrm{~g})$ and root biomass $(0.56 \mathrm{~g})$ was recorded in weed free treatment which was at par with Pendimethalin as PE followed by one hand weeding at 20 DAS $(24.15,0.26 \mathrm{~g}$ and $0.50 \mathrm{~g}$, respectively). Among various treatments, weed free recorded $(99.77 \%)$ higher nodules number over weedy check. However, application of Pendimethalin (PE) followed by one hand weeding 20 DAS, Propaquizafop followed by Imezathyper) as post emergence at 20 DAS and Pendimethalin (PE) followed by Imezathyper (POE) at 20 DAS were recorded lower nodules number plant as compare to weed free by $10.65,15.39$ and $25.26 \%$, respectively. Hand weed was recorded more nodules/plant and root biomass. Increased in number of nodules and root biomass under hand weeding treatments due to improve aeration of rhizosphere and improve soil condition. These results were similar with findings of Khairnar et al. (2013) and Chhodovadia et al. (2011).

\section{Effects on seed yield}

Result showed that weed management practices significantly influence seed yield (Fig 1). Weed free treatment produced significantly highest seed yield (10.10 q/ha) which was at par on Pendimethalin (PE) followed by one hand weeding 20 DAS (9.49 q/ha) and Shaked (Propaquizafop + Imezathyper) as POE at 20 DAS (9.47 q/ha). Pendimethalin (PE) followed by one hand weeding 20 DAS, Shaked as post emergence at 20 DAS and Pendimethalin (PE) followed by Imezathyper (POE) at 20 DAS were recorded lower seed yield as compare to weed free by $6.03,6.23$ and $10.49 \%$, respectively. Higher growth attributes lead to higher DM production ultimately leads to higher yield. This might be because of efficient weed control by herbicides when combined with hand weeding which finally influenced growth parameters and yield. Raman and Krishnamoorthy (2005) were also found the similar results.

\section{Effects on nutrients content and uptake by seed}

The results revealed that weed management practices does not reported significant variation on $\mathrm{N}, \mathrm{P}$ and $\mathrm{K}$ content of seed (Fig 2) but nutrients uptake significantly affected by weed management practices. The highest nitrogen, phosphorus and potassium uptake by seed (39.10, 4.74 and

Table 1: Effects of different weed management practices on plant height, number of branches/plant and number of leaves/plant at 30 DAS and Harvest.

\begin{tabular}{lcccccc}
\hline \multirow{2}{*}{ Treatments } & \multicolumn{2}{c}{ Plant height $(\mathrm{cm})$} & \multicolumn{2}{c}{ Number of branches/plant } & \multicolumn{2}{r}{ Number of leaves/plant } \\
\cline { 2 - 6 } & 30 DAS & Harvest & 30 DAS & Harvest & 30 DAS & Harvest \\
\hline Weed check & 16.07 & 32.17 & 1.97 & 2.49 & 13.93 & 20.87 \\
Weed free & 32.70 & 57.00 & 4.30 & 5.87 & 25.10 & 48.03 \\
Pendimethalin (PE) & 21.43 & 42.13 & 3.15 & 3.38 & 18.03 & 29.80 \\
Pendimethalin (PE) followed by one HW 20 DAS & 28.40 & 53.80 & 3.74 & 5.02 & 20.93 & 41.37 \\
Imezathyper (POE) at 20 DAS & 21.60 & 42.93 & 3.42 & 3.53 & 18.13 & 31.73 \\
(Propaquizafop + Imezathyper) as POE at 20 DAS & 24.60 & 48.07 & 3.50 & 4.08 & 19.93 & 39.47 \\
Pendimethalin (PE) followed by Imezathyper & 23.00 & 45.67 & 3.47 & 3.75 & 18.73 & 35.00 \\
(POE) at 20 DAS & & & & & \\
Pendimethalin (PE) followed by Quizolofop & 22.03 & 43.67 & 3.48 & 3.63 & 19.03 & 33.10 \\
ethyl at 20 DAS & & & & & \\
SEM ( \pm ) & 1.39 & 2.81 & 0.17 & 0.26 & 1.06 & 2.12 \\
CD (p=0.05) & 4.20 & 8.51 & 0.52 & 0.79 & 3.20 & 6.43 \\
\hline
\end{tabular}

Table 2: Effects of different weed management practices on root biomass/plant, number of nodule/plant and nodule dry weight at 40 DAS and LAI at harvest.

\begin{tabular}{|c|c|c|c|c|}
\hline Treatments & $\begin{array}{c}\text { Root biomass/ } \\
\text { plant (g) }\end{array}$ & $\begin{array}{c}\text { Number of } \\
\text { nodule plant }\end{array}$ & $\begin{array}{l}\text { Noduledry } \\
\text { weight (g) }\end{array}$ & LAI \\
\hline & 40 DAS & 40 DAS & 40 DAS & Harvest \\
\hline Weed check & 0.31 & 13.53 & 0.13 & 2.30 \\
\hline Weed free & 0.56 & 27.03 & 0.29 & 4.11 \\
\hline Pendimethalin (PE) & 0.38 & 17.17 & 0.18 & 2.77 \\
\hline Pendimethalin (PE) followed by one HW 20 DAS & 0.50 & 24.15 & 0.26 & 3.57 \\
\hline Imezathyper (POE) at 20 DAS & 0.40 & 17.70 & 0.19 & 2.87 \\
\hline (Propaquizafop + Imezathyper) as POE at 20 DAS & 0.43 & 22.87 & 0.22 & 3.40 \\
\hline Pendimethalin (PE) followed by Imezathyper (POE) at 20 DAS & 0.42 & 20.20 & 0.21 & 2.95 \\
\hline Pendimethalin (PE) followed by Quizolofop ethyl at 20 DAS & 0.41 & 18.23 & 0.20 & 2.92 \\
\hline $\operatorname{SEM}( \pm)$ & 0.03 & 1.16 & 0.01 & 0.18 \\
\hline$C D(p=0.05)$ & 0.08 & 3.52 & 0.04 & 0.55 \\
\hline
\end{tabular}


$14.67 \mathrm{~kg} / \mathrm{ha}$, respectively) was observed under weed free followed by Pendimethalin (PE) followed by one hand weeding 20 DAS $(35.65,4.32$ and $13.05 \mathrm{~kg} / \mathrm{ha}$, respectively). All weed control measures tended to enhance the nutrient uptake by seed compared to weedy check (Table 3 ). As nutrient uptake by crop is a function of yield and nutrient content. Application of herbicides and hand weeding leads to, more uptakes of nutrients by crop due to minimum crop weed competition had parallel increased in nutrient availability, superior crop growth and higher crop biomass production tied with more nutrient content. These results are harmony with finding of Chhodavadia et al. (2013), Komal et al. (2015) and Kaur et al. (2010).

\section{Effects on seed quality parameters}

The data mentioned in Table 4 showed that the use of weed management treatment significantly affected the germination per cent, shoot, root and seedling length of mungbean. Weed free treatment recorded significantly highest germination percentage (98\%) followed by Pendimethalin

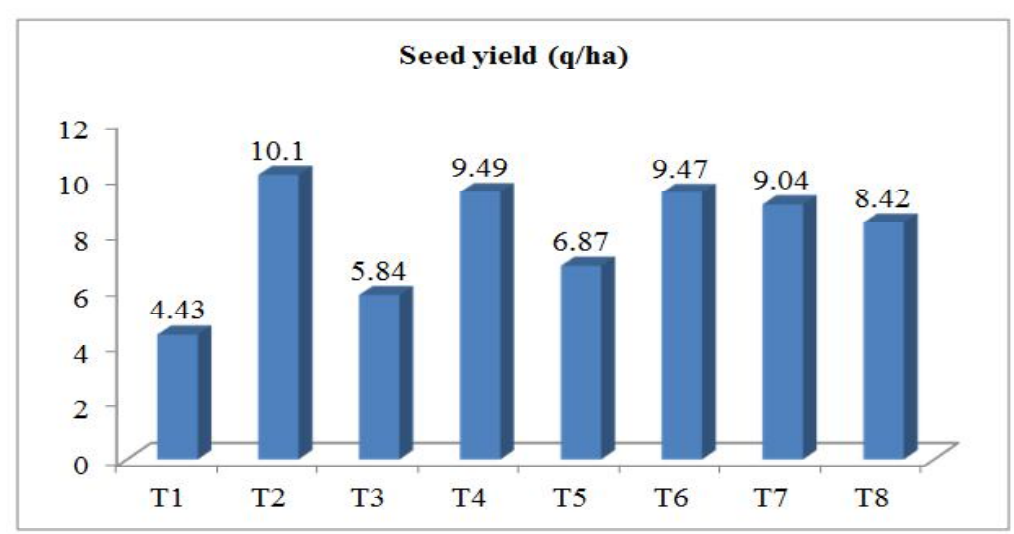

Fig 1: Effects of weed management practices on seed yield.

$\mathrm{T}_{1}$ - Weedy check, $\mathrm{T}_{2}$ - Weed free, $\mathrm{T}_{3}$ - Pendimethalin (PE) @ $0.75 \mathrm{~kg} / \mathrm{ha}, \mathrm{T}_{4^{-}}$Pendimethalin $\mathrm{fb} \mathrm{HW}$ at $20 \mathrm{DAS}, \mathrm{T}_{5}$ - Imezathyper (POE) @ $75 \mathrm{~g} / \mathrm{ha}, \mathrm{T}_{6}$ - Shaked (Propaquizafop + Imezathyper) (2 I/ha) (POE), $\mathrm{T}_{7}$ - Pendimethalin @ $0.75 \mathrm{~kg} / \mathrm{ha} f \mathrm{fb}$ Imezathyper @ $75 \mathrm{~g} / \mathrm{ha}$ at 20 DAS and $\mathrm{T}_{8}$ - Pendimethalin @ $0.75 \mathrm{~kg} / \mathrm{ha}$ fb Quizolofop ethyl @ $50 \mathrm{~g} / \mathrm{ha}$ at 20 DAS.

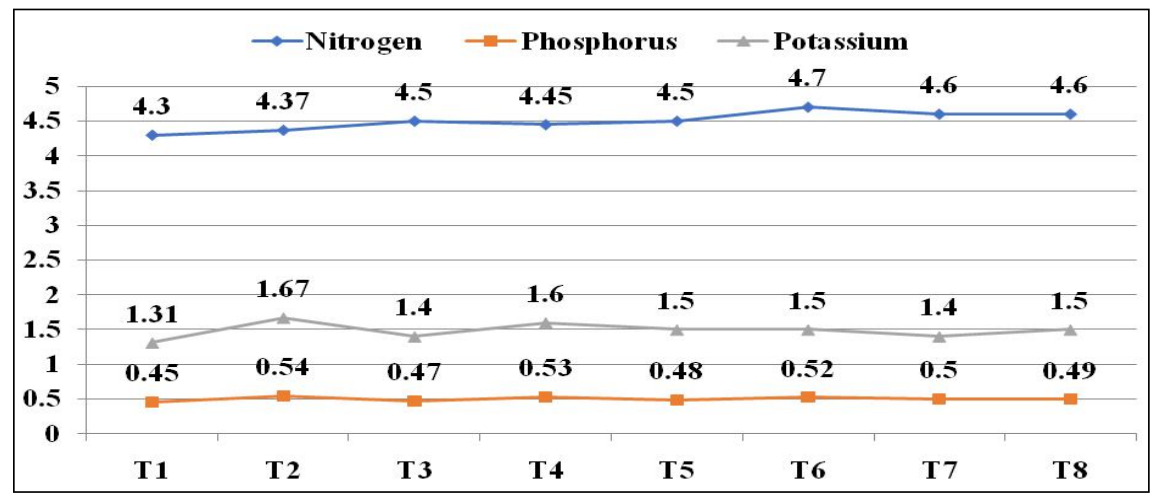

Fig 2: Effects of weed management practices on $\mathrm{N}, \mathrm{P}$ and $\mathrm{K}$ content (\%) in seed.

Table 3: Effects of different weed management treatments on $\mathrm{N}, \mathrm{P}$ and $\mathrm{K}$ uptake by seed.

\begin{tabular}{lccc}
\hline Treatments & N uptake by & P uptake by & $\begin{array}{c}\text { K uptake by } \\
\text { seed (kg/ha) }\end{array}$ \\
\hline Weed check & 15.62 & 1.63 & 4.76 \\
Seed free & 39.10 & 4.74 & 14.67 \\
Pendimethalin (PE) & 21.81 & 2.28 & 6.79 \\
Pendimethalin (PE) followed by one HW 20 DAS & 35.65 & 4.32 & 13.05 \\
Imezathyper (POE) at 20 DAS & 26.27 & 2.80 & 8.76 \\
(Propaquizafop + Imezathyper) at 20 DAS & 38.26 & 4.23 & 12.21 \\
Pendimethalin (PE) followed by Imezathyper at 20 DAS & 34.93 & 3.80 & 10.63 \\
Pendimethalin (PE) followed by Quizolofop ethyl & 32.92 & 3.51 & 10.74 \\
SEM $( \pm)$ & 1.02 & 0.20 & 0.32 \\
CD $(p=0.05)$ & 3.10 & 0.92 & 0.96 \\
\hline
\end{tabular}


Yield and Seed Quality of Summer Green Gram as Influenced by Weed Management under Zero Tillage

Table 4: Effects of different weed control treatments on germination \%, shoot, root and seedling length.

\begin{tabular}{lcccc}
\hline Treatments & $\begin{array}{c}\text { Germination } \\
\text { percentage }\end{array}$ & $\begin{array}{c}\text { Shoot } \\
\text { length }(\mathrm{cm})\end{array}$ & $\begin{array}{c}\text { Root } \\
\text { length }(\mathrm{cm})\end{array}$ & $\begin{array}{c}\text { Seedling } \\
\text { length }(\mathrm{cm})\end{array}$ \\
\cline { 2 - 5 } Weed check & 85.33 & 22.57 & 10.10 & 32.67 \\
Weed free & 98.00 & 25.63 & 14.20 & 39.83 \\
Pendimethalin (PE) & 92.33 & 23.17 & 12.50 & 35.67 \\
Pendimethalin (PE) followed by one HW 20 DAS & 95.33 & 24.43 & 13.73 & 38.17 \\
Imezathyper (POE) at 20 DAS & 93.67 & 23.27 & 12.83 & 36.10 \\
(Propaquizafop + Imezathyper) as POE at 20 DAS & 94.33 & 23.47 & 13.33 & 36.80 \\
Pendimethalin (PE) followed by Imezathyper (POE) at 20 DAS & 94.00 & 23.13 & 12.83 & 35.97 \\
Pendimethalin (PE) followed by Quizolofop ethyl at 20 DAS & 94.33 & 23.63 & 13.07 & 36.70 \\
SEM $( \pm)$ & 0.51 & 0.20 & 0.26 & 0.28 \\
CD $(p=0.05)$ & 1.55 & 0.60 & 0.78 & 0.85 \\
\hline
\end{tabular}

Table 5: Effects of different weed management treatments on seedling dry weight, seedling vigour index I and II.

\begin{tabular}{lccc}
\hline Treatments & $\begin{array}{c}\text { Seedling dry } \\
\text { weight }(\mathrm{g})\end{array}$ & $\begin{array}{c}\text { Seedling vigour } \\
\text { index I }\end{array}$ & $\begin{array}{c}\text { Seedling vigour } \\
\text { index II }\end{array}$ \\
\hline Weed check & 0.13 & 2787.73 & 11.75 \\
Weed free & 0.16 & 3903.33 & 14.96 \\
Pendimethalin (PE) & 0.14 & 3293.33 & 13.60 \\
Pendimethalin (PE) followed by one HW 20 DAS & 0.15 & 3638.50 & 14.31 \\
Imezathyper (POE) at 20 DAS & 0.15 & 3381.63 & 13.96 \\
(Propaquizafop + Imezathyper) as POE at 20 DAS & 0.15 & 3471.70 & 14.15 \\
Pendimethalin (PE) followed by Imezathyper at 20 DAS & 0.15 & 3381.07 & 13.91 \\
Pendimethalin (PE) followed by Quizolofop ethyl at 20 DAS & 0.15 & 3461.90 & 14.30 \\
SEM $( \pm)$ & 0.02 & 35.51 & 2.18 \\
CD $(p=0.05)$ & 0.01 & 107.70 & $\mathrm{NS}$ \\
\hline
\end{tabular}

as PE followed by one hand weeding at 20 DAS (95.33\%) and Pendimethalin as PE followed by Quizolofop ethyl at 20 DAS (94.33\%). Weedy check was observed significantly lowest germination percentage $(85.33 \%)$. Weed free was recorded significantly highest shoot, root and seedling length (25.63, 14.20 and $39.83 \mathrm{~cm}$, respectively) followed by pendimethalin as PE followed by one hand weeding at 20 DAS $(24.43,13.73$ and $38.17 \mathrm{~cm}$, respectively) which was at par on pendimethalin as PE followed by Quizolofop ethyl at 20 DAS over weed check. Weedy check was recorded significantly lowest shoot, root and seedling length (22.5, 10.1 and $32.67 \mathrm{~cm}$, respectively).

The analyzed data on seedling dry weight, seed vigour index - I of green gram is recorded in Table 5 which showed that significant effect observed due to the weed management treatments same time vigor index II did not significantly affected. Weed free was observed significantly highest seedling dry weight, vigour index I and II $(0.158 \mathrm{~g}, 3903$ and 14.96, respectively) followed by Pendimethalin as PE followed by hand weeding 20 DAS $(0.156 \mathrm{~g}, 3638$ and 14.31 respectively). Weedy check was recorded significantly lowest seedling dry weight, seed vigour index I and II (0.13 g, 2787.67 and 11.75).

Higher seed quality might be due to less competition with crop by weeds for nutrients, moisture, space and air, by control of weeds, finally leads to improve health, growth and seed quality parameter of mungbean. Pendimethalin as PE followed by one hand weeding at 20 DAS and Shaked treatment significantly reduce weed infestation and improve seed quality parameters. These results are harmony with finding of Chaubey et al. (2016).

\section{CONCLUSION}

Based on finding of experiment it may concluded that application of Shaked (Propaquizafop + Imezathyper) @ 2 I/ha at 20 DAS may recommended to higher growth, yield and seed quality of summer green gram under zero tillage condition.

\section{ACKNOWLEDGEMENT}

The authors are heartily thankful to Director, ICAR-NDRI, Karnal for provide all the facilities and financial support for conduct the study.

\section{REFERENCES}

Abdulbaki, A.A. and Anderson, J.D. (1973). Vigor determination in soybean seed by multiple criteria 1. Crop Science. 13(6): 630-633.

Ali, S., Patel, J.C., Desai, L.J. and Singh, J. (2011). Effect of herbicides on weeds and yield of rainy season greengram [Vigna radiata (L.) Wilczek). Legume Research. 34(4): 300-303. 
Butter, G.S., Aggarwal, N. and Singh, S. (2008). Efficacy of different herbicides in chickpea (Cicer arietinum L.) under irrigated condition of Punjab. Indian Journal Weed Science. 40(3 and 4): $169-171$.

Chaubey, T., Manimurugan, C., Gupta, N., Kumar, R., Singh, P.M. and Singh, B., (2016). Effect of different weed management practices on seed yield and quality of vegetable pea. Vegetable Science. 43(1): 142-144.

Chhodavadia, S.K., Mathukiya, R.K. and Dobariya, V.K. (2013). Pre and post-emergence herbicides for integrated weed management in summer greengram. Indian Journal of Weed Science. 45(2): 137-139.

Chhodavadia, S.K., Sagarka, B.K. and Goh, B.S. (2011). Integrated management for improved weed suppression in summer green gram (Vigna radiata). International Journal of Life Science. 9(2): 1577-1580.

Choudhary, R., Singh, P., Sidhu, H.S., Nandal, D.P., Jat, H.S. and Jat, M.L. (2016). Evaluation of tillage and crop establishment methods integrated with relay seeding of wheat and mungbean for sustainable intensification of cotton-wheat system in South Asia. Field Crops Research, 199: 31-41.

Das, T.K. and Yaduraju, N.T. (2011). Effects of missing-row sowing supplemented with row spacing and Nitrogen on weed competition and growth and yield of wheat. Crop and Pasture Science. 62(1): 48-57.

Das, T.K. and Yaduraju, N.T. (2012). The effects of combining modified sowing methods with herbicide mixtures on weed interference in wheat. International Journal of Pest Management. 58(4): 311-320.

Dhakal, Y., Meena, R.S., Verma, S.K. and Singh, A. (2015). Growth, yield and nutrient content of mungbean (Vigna radiata L.) in response to INM in eastern Uttar Pradesh. India. Bangladesh journal of Botany. 44(3): 479-482.

Dungarwal, H.S., Chaplot, P.C. and Nagda, B.L. (2003). Chemical weed control in mungbean. Indian Journal of Weed Science. 35 (3 and 4): 283-294

Gomez, K.A. and Gomaz, A.A. (1984). Statistical Procedures for Agricultural Research. J. Wiley and Sons, Singapore.

ISTA, (2019). Hand book International Rules for Seed Evaluation Methods published by International Seed Testing Agency Basserdorf, Switzerland.

Kaur, G., Brar, H.S. and Singh, G. (2010). Effect of weed management on weeds, nutrient uptake, nodulation, growth and yield of summer mungbean (Vigna radiata). Indian Journal of Weed Science. 42 (1 and 2): 114-119.
Khairnar, C.B., Goud, V.V. and Sethi, H.N. (2013). Pre- and postemergence herbicides for weed management in mungbean. Indian Journal of Weed Science. 46(4): 392-395.

Komal Singh, S.P. and Yadav, R.S. (2015). Effect of weed management on growth, yield and nutrient uptake of greengram. Indian Journal of Weed Science. 47(2): 206-210

Kumar, A.,IMalik, Y.P. and Yadav, A. (2006). Weed management in mungbean. Journal of Agriculture Research. 36(2): 127-9.

Kumar, N., Hazra, K.K. and Nadarajan, N. (2016). Efficacy of preand post-emergence herbicides in rainy season greengram (Vigna radiata). Indian Journal of Agricultural Science. 87(9): 1219-1224.

Mallikarjun, Ram H., Kumar, R., Singh, M., Meena, R.K. and Kumar, R. (2021). Effect of rhizobium inoculation and tillage practices on fodder cowpea (Vigna unguiculata). Legume Research. DOI: 10.18805/LR-4373.

Pandey, A.K., Singh, P., Prakash, V., Singh, R.D. and Chauhan V.S. (1999). Direct and residual effect of weed control measures in maize (Zea mays) and wheat (Triticum aestivum) cropping system under mid-hill conditions of northwestern Himalayas. Indian Journal of Weed Science. 31(3 and 4): 204-9.

Peoples, M., Herridge, D. and Ladha, J. (2018). Biological Nitrogen fixation: An efficient source of nitrogen for sustainable Agricultural Production. Plant and Soil Journal. 174: 3-28.

Raghvani, B.R., Goyal, S.N., Patel, J.C. and Malavia, D.D. (1985). Weed competition in mungbean. Indian Journal of Weed Science. 17(1): 18-21.

Raman, R. and Krishnamoorthy, R. (2005). Nodulation and yield of mungbean (Vigna radiata) influenced by integrated weed management practices. Legume Research. 28(2): 128-130.

Singh, K., Ram H., Kumar, R., Meena, R.K., Kumar, R. and Manisha (2021). Effect of Weed Management Practices on Weed Dynamics, Nutrient Depletion, Productivity and Profitability of Summer Mungbean (Vigna radiata) under Zero Tillage Condition. Legume Research. DOI: 10.18805 /LR-4497.

Yadav, K.V., Singh, D.P., Sharma, S.K. and Kishor, K. (2017). Use of phosphorus for maximization of summer greengram [Vigna radiata (L.) Wilszeck] productivity under sub humid condition of Rajasthan, India. Journal of Pharmacognosy and Phytochemistry. 6(4): 01-03. 